\title{
Extracranial Spheno-Ethmoidal Sinus Meningioma: Case Report
}

\author{
Ekstrakraniyal Sfeno-Etmoidal Sinüs Menenjiyomu: Olgu Sunumu
}

\author{
Ryosuke MORI ${ }^{1,2}$, Luigi Maria CAVALLO ${ }^{1}$, Elia GUADAGNO ${ }^{3}$, Alessia IMPERATO ${ }^{1}$, Yuichi MURAYAMA², \\ Paolo CAPPABIANCA ${ }^{1}$ \\ ${ }_{1}^{1}$ Università degli Studi di Napoli Federico II, Department of Neurosciences, Reproductive and Odontostomatological Sciences, Division of \\ Neurosurgery, Naples, Italy \\ ${ }^{2}$ The Jikei University, School of Medicine, Department of Neurosurgery, Tokyo, Japan \\ ${ }^{3}$ Università degli Studi di Napoli Federico II, Department of Advanced Biomedical Sciences, Division of Pathology, Naples, Italy
}

Corresponding Author: Mori RYOSUKE / E-mail: ryotam@jikei.ac.jp

\begin{abstract}
Extracranial meningiomas of the paranasal sinus are the rare tumors of unclear etiology. We report a case of primary extracranial meningioma arising from the roof of the sphenoid sinus.

A 60-year-old female presented with 5-month history of right visual disturbance. Imaging studies showed a mass in the sphenoid sinus extending into posterior ethmoid sinus. The tumor was resected completely including the affected bone of anterior cranial base via the endonasal endoscopic approach. Pathological diagnosis was meningothelial meningioma.

On the basis of imaging features and intraoperative findings, the tumor was diagnosed as primary extracranial meningioma of the sphenoethmoid sinus. Recent advancement of skull base surgery technique allows removing this rare tumor completely and safely without complications such as cerebrospinal fluid leakage. This is the first report of the management of spheno-ethmoid sinus meningioma with the skull base surgery technique.
\end{abstract}

KEYWORDS: Extracranial meningioma, Sphenoid sinus, Ethmoid sinus, Skull base surgery, Endoscopic surgery

öz

Paranazal sinüslerin ekstrakraniyal menenjiyomları, etiyolojisi belirsiz nadir tümörlerdir. Sfenoid sinüs çatısından kaynaklanan bir primer ekstrakraniyal menenjiyom olgusunu sunuyoruz.

60 yaşındaki kadın hasta 5 aydır sağ tarafta görme rahatsızlığı ile başvurdu. Görüntüleme çalışmaları sfenoid sinüste posterior etmoid sinüse uzanan bir kitle saptadı. Tümör endonazal endoskopik yaklaşımla anterior kraniyal tabanın etkilenen kemiği dahil tamamen çıkartıldı. Patolojik tanı meningotelyal menenjiyomdu.

Görüntüleme özellikleri ve ameliyat bulgularına dayanarak, tümöre sfeno-etmoid sinüs primer ekstrakraniyal menenjiyomu tanısı konuldu. Kafa tabanı cerrahisi tekniklerindeki güncel gelişmeler bu nadir tümörün beyin omurilik sıvısı kaçağı gibi komplikasyonlar olmadan, tamamen ve güvenle çıkarılmasını sağlamaktadır. Bu makale kafa tabanı cerrahisi tekniği ile sfeno-etmoid sinüs menenjiyomu tedavisinin ilk bildirimidir.

ANAHTAR SÖZCÜKLER: Ekstrakraniyal menenjiyom, Sfenoid sinüs, Etmoid sinüs, Kafa tabanı cerrahisi, Endoskopik cerrahi

\section{INTRODUCTION}

Meningioma is a slow-growing, generally benign, and common neoplasms occurring in the intracranial region. However, primary extracranial meningiomas are very rare, accounting for $1-2 \%$ of all meningiomas $(5,6)$. Among these extracranial meningiomas, meningiomas arising from sinonasal tract were reported to represent only $24 \%$ (14). We describe a case of primary extracranial meningioma arising from the roof of the sphenoid sinus treated with an endoscopic endonasal approach. And with a review of literatures, we report the possible origin and therapeutic characteristics of this rare tumor.

\section{CASE REPORT}

A 60-year-old female presented with a 5-month history of right visual change. Physical examination revealed a decreased visual acuity in right eye, and computerized visual field examination showed generalized reduction of retinal sensibility in all sectors of visual field. Computed tomography (CT) demonstrated a soft tissue dense mass in the sphenoid sinus extending into posterior ethmoid sinuses. There was hyperostosis of the roof of sphenoid sinus, but no bony defect of the anterior cranial base was noted (Figure 1A,B). Magnetic resonance imaging (MRI) showed an enhanced mass similar to $C T$ findings without intracranial mass lesion (Figure $2 A, B$ ).

We performed complete resection of the tumor via endonasal endoscopic approach. The tumor was reddish-yellow in color, 
elastic firm and well circumscribed. The tumor was attached to the roof of the sphenoid sinus firmly. The roof was thickened but fragile, that appeared to be infiltrated by the tumor. The thickened bone was drilled away and removed as well as the tumor (Figure $3 \mathrm{~A}-\mathrm{C}$ ). On the histologic examination, the tumor was arranged in nodules that mainly showed a syncytial pattern of growth and occasionally, psammoma bodies.
Neoplastic cells had an immunohistochemical positivity for the epithelial membrane antigen (EMA). The proliferating index evaluated with Ki67 showed a low Labeling Index (2\%), and overexpression of the progesterone receptor (in around $100 \%$ of the nuclei) was observed. All these aspects were consistent with a diagnosis of meningothelial meningioma (grade I WHO) (Figure 4A-F).
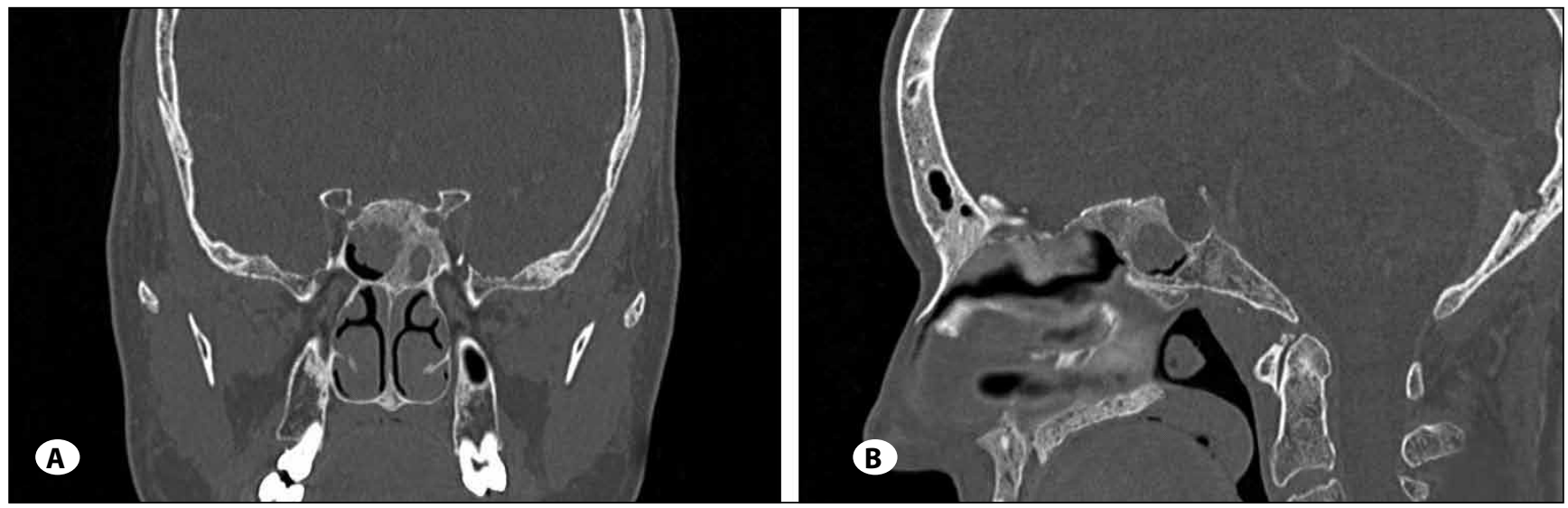

Figure 1: A) Coronal and B) sagittal section of CT showing a mass in the sphenoid sinus and hyperostosis of the roof and septum of the sphenoid sinus.
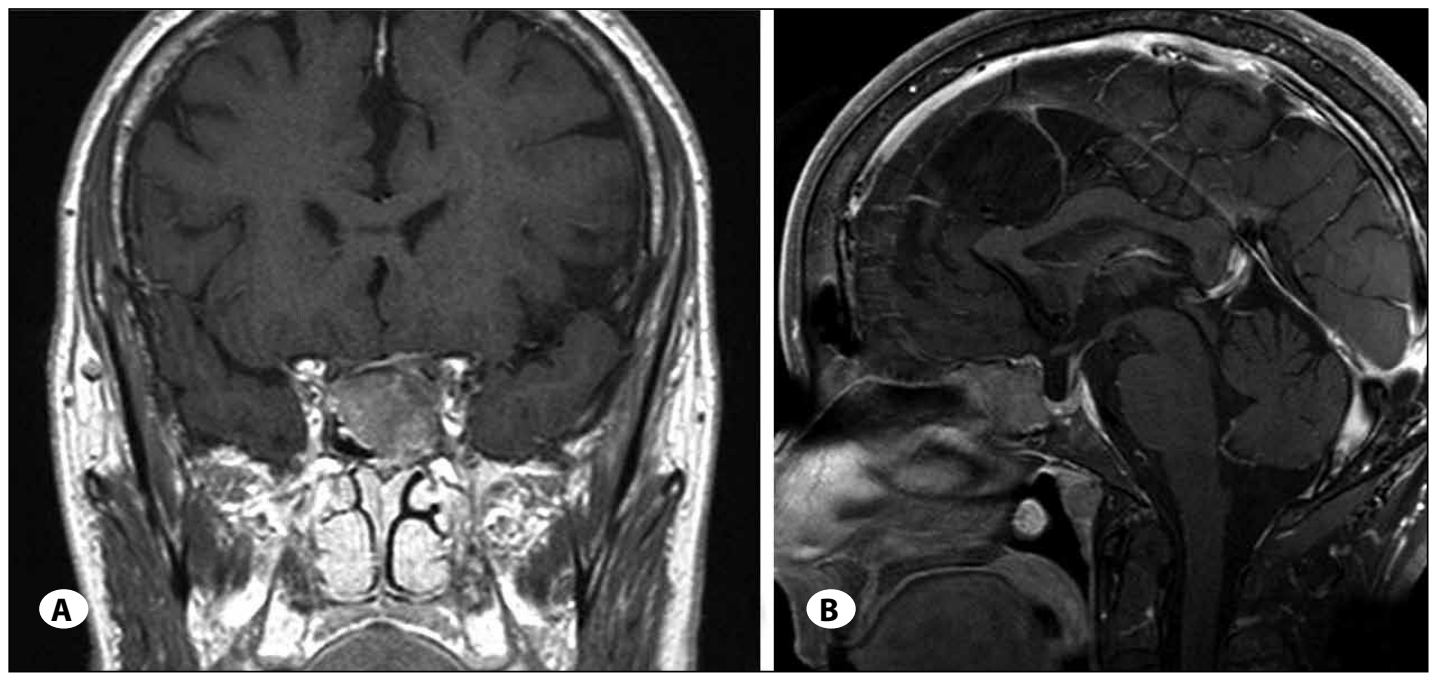

Figure 2: A) Coronal and B) sagittal section of MRI demonstrating a mass in the sphenoid sinus without intracranial lesion.
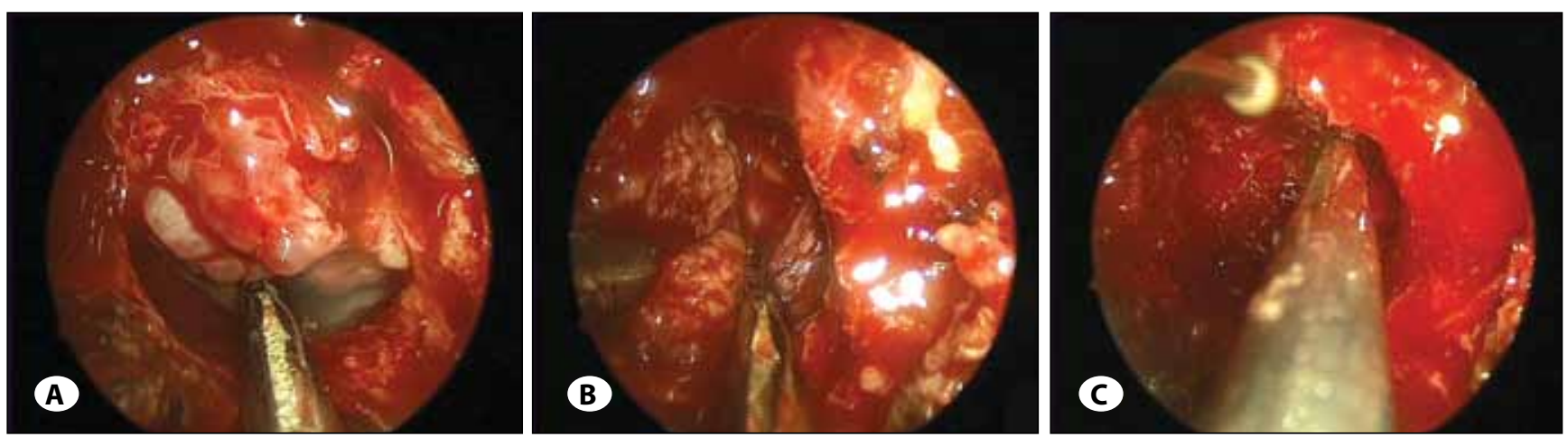

Figure 3: Intraoperative findings; A) A mass in the sphenoid sinus after wide sphenoidectomy, B) Dissecting the tumor with attachment at the roof of the sphenoid sinus, $\mathbf{C}$ ) Removing the affected bone of the anterior cranial base with drill. 


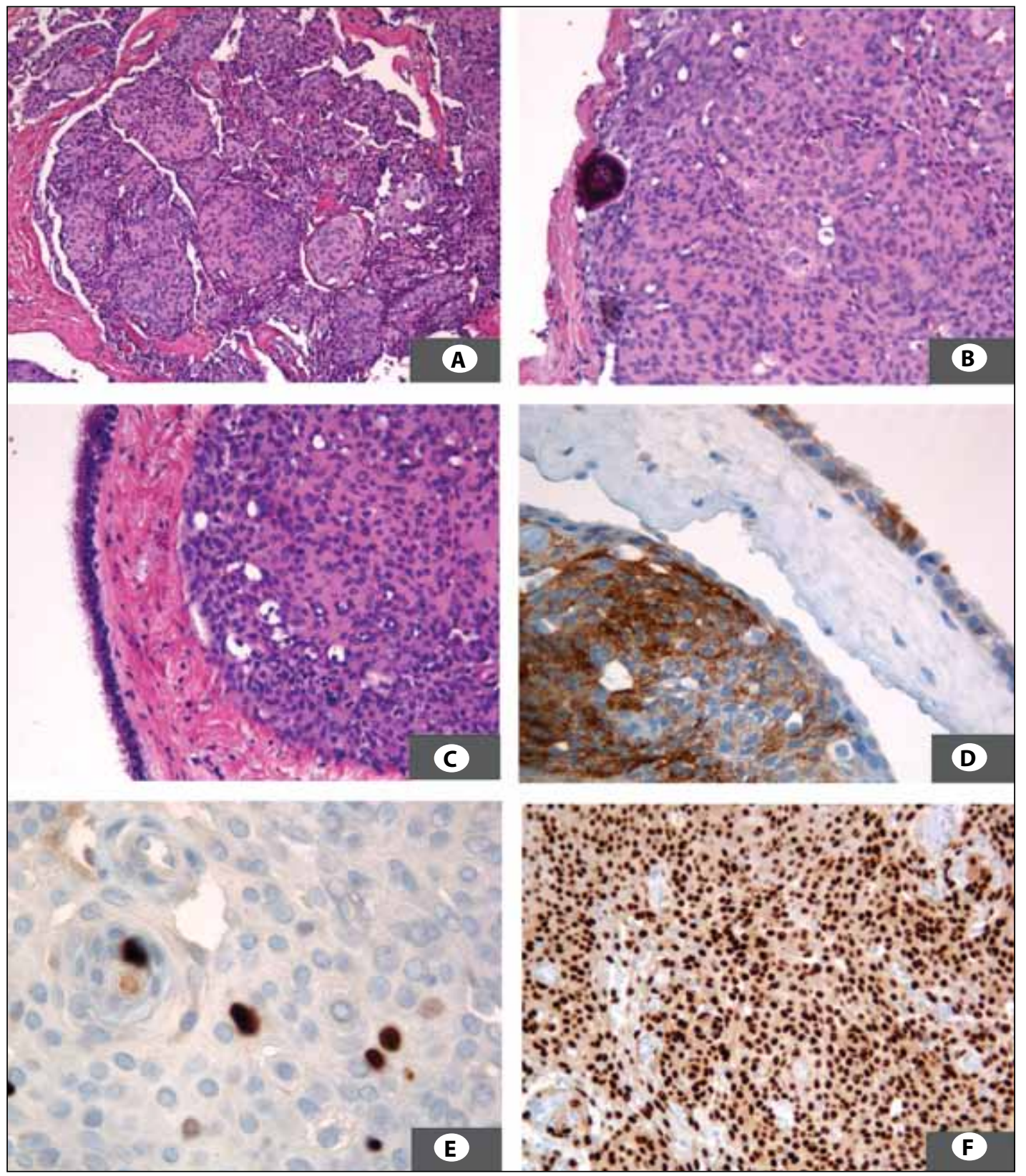

Figure 4: A) Nodules of meningioma with the classic syncytial pattern (hematoxylin and eosin stain x10), B) On the left, a psammoma body (hematoxylin and eosin stain $\times 20$ ), C) The neoplasm pushes the respiratory mucosa from the underlying corion (hematoxylin and eosin stain),

D) EMA positivity,

E) Ki67 with a Labeling Index around $2 \%$,

F) Progesterone receptor positivity in around $100 \%$ of neoplastic cells.
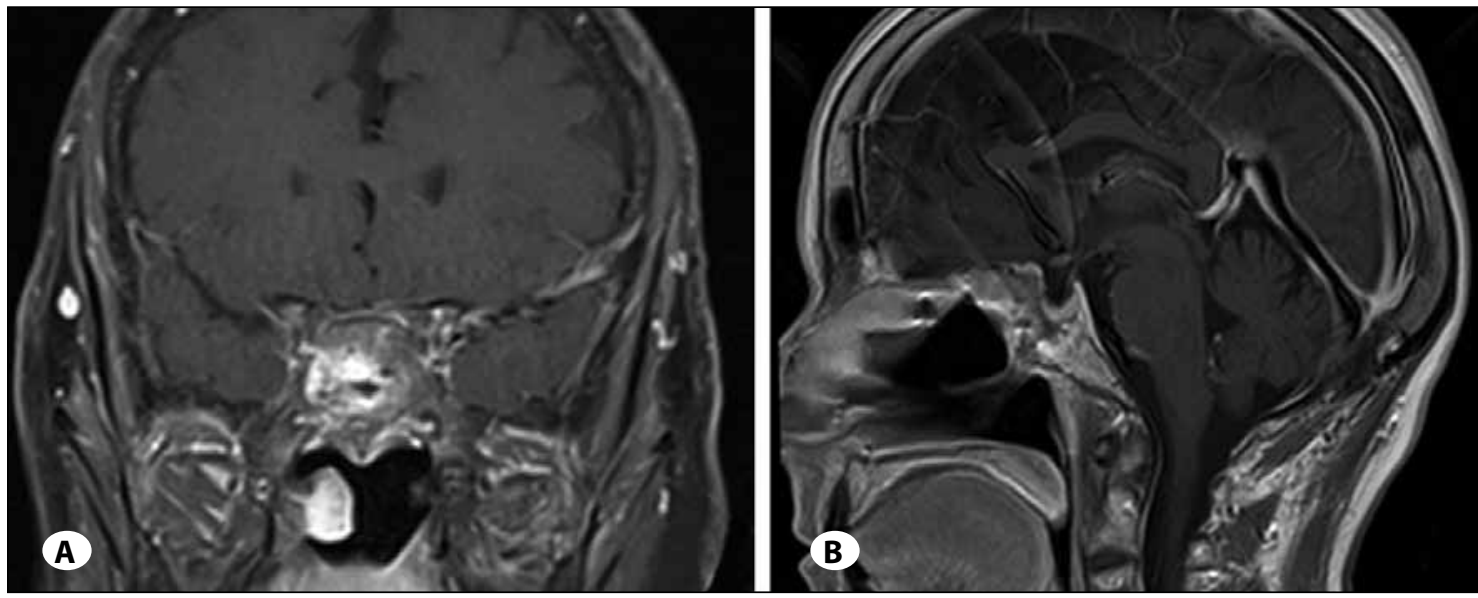

Figure 5:

A) Coronal and B) sagittal section of early stage postoperative MRI demonstrating a complete removal of the tumor. 
The postoperative course was uneventful and visual acuity improved progressively. Three months postoperative MRI showed complete removal of the tumor (Figure 5A,B).

\section{DISCUSSION}

Meningiomas are benign slow-growing tumors, which represent between $13 \%$ and $26 \%$ of all primary intracranial tumors (10). They are usually found intracranially; extracranial meningiomas are rare with an incidence of $1-2 \%$ of all meningiomas $(5,6)$. Extracranial meningiomas are classified into two types according to the anatomical relation between intra- and extracranial regions (9). They are considered primary when tumor arises independently, and secondary when they show direct attachment to the intracranial region. Most of extracranial meningiomas are of secondary type $(7,12)$, however, our case was considered to be primary by the fact that there was no bone defect of anterior cranial base and no intracranial lesion.

The origin of extracranial meningioma is still unclear, however, there are several hypotheses that these tumor could arise from arachnoid cells existing in nerve sheaths or from ectopic arachnoid cells entrapped extracranially $(7,17)$, or arise from pleuripotential mesenchymal cells (14). As the tumor attachment was adjacent to cranial base in our case, we believe that the tumor developed from ectopic arachnoid cells.

The mainly affected areas of extracranial meningiomas are the cervico-facial region such as scalp (40.4\%), ear and temporal bone (26\%), and sinonasal tract (24\%) (14). Among cases involving the sinonasal tract, Thompson et al. described that most of the tumors were found to affect more than one sinus or a combination of nasal cavity and paranasal sinuses and the most commonly affected sinus was the frontal sinus (16). A sinonasal meningioma originating from the sphenoid sinus is relatively rare, whereas there are some isolated case reports of sinonasal meningioma mainly involving the ethmoid sinus $(1,8,11,13)$.

Clinical features of sinonasal tract meningiomas reported in the literature are non-specific and include nasal mass, nasal obstruction, nasal discharge, epistaxis, sinusitis, headache, and less frequently visual changes (16). Visual symptoms are considered to be related to the mass effect and compression of the optic nerve, thus tumor removal and decompression is essential to improve visual acuity, although blindness does not always improve with removal of the tumor $(14,16)$.

Histologically, the majority of these meningiomas are benign (WHO grade I) as well as intracranial meningiomas: meningothelial meningioma (80\%), transitional meningioma (7\%) and metaplastic meningioma (3\%) (16). WHO grade I tumors have a lower rate of recurrence (7-20\%) after subtotal resection (10).

The only curative treatment for meningiomas is complete resection that includes the attachment of the tumor to avoid tumor recurrence. To achieve complete resection, the endoscopic approach offers some advantages $(2,15)$. It provides a wider surgical field, close-up and multi-angled visualization and minimal invasiveness (4). Furthermore, direct observation of the roof of the sphenoid sinus allows precise exposure of the attachment. There are several reports on endoscopic sinus surgery to remove a paranasal sinus meningioma $(8,11)$, however, the skull base in which tumor was infiltrated was left alone because of the risk of cerebrospinal fluid (CSF) leakage (8). Thus this is the first report of the management of paranasal sinus meningioma with the skull base surgery technique. Recent advancement of endoscopic skull base surgery allows removing the cranial base safely and dealing with CSF leakage (3). We should take into consideration removing not only tumor bulk but also the affected bone to achieve complete resection.

\section{REFERENCES}

1. Arias Marzan F, de Lucas Carmona G, Alvarez Florez M, Febles Garcia P: Extracranial meningiomas of the paranasal sinuses. Acta Otorrinolaringol Esp 61:238-240, 2010

2. Cappabianca P, Cavallo LM, de Divitiis O, Solari D, Esposito F, Colao A: Endoscopic pituitary surgery. Pituitary 11:385-390, 2008

3. Cavallo LM, Messina A, Esposito F, de Divitiis O, Dal Fabbro M, de Divitiis E, Cappabianca P: Skull base reconstruction in the extended endoscopic transsphenoidal approach for suprasellar lesions. J Neurosurg 107:713-720, 2007

4. Cavallo LM, Prevedello D, Esposito F, Laws ER Jr, Dusick JR, Messina A, Jane JA Jr, Kelly DF, Cappabianca P: The role of the endoscope in the transsphenoidal management of cystic lesions of the sellar region. Neurosurg Rev 31:55-64; discussion 64, 2008

5. Fernandez Liesa R, Rivares Esteban J, Perez Obon J, Ros Mendoza L, Gambo Grasa P, de Miguel Hernandez D: Primary meningioma of the nose and the paranasal sinus. Ann Otolaryngol Chir Cervicofac 108:34-37, 1991

6. Friedman $C D$, Costantino PD, Teitelbaum B, Berktold RE, Sisson GA Sr: Primary extracranial meningiomas of the head and neck. Laryngoscope 100:41-48, 1990

7. Ho KL: Primary meningioma of the nasal cavity and paranasal sinuses. Cancer 46:1442-1447, 1980

8. Kainuma K, Takumi Y, Uehara T, Usami S: Meningioma of the paranasal sinus: A case report. Auris Nasus Larynx 34:397-400, 2007

9. Lingen MW, Rao SM, Hutten MC, Pelzer HJ: Primary ectopic meningioma of the maxillary sinus: Case report and review of the literature. Head Neck 17:258-262, 1995

10. Louis DN SB, Budka H, von Deimling A, Kepes JJ (ed): Meningiomas. Lyon: IARC Press, 2000

11. Mnejja M, Hammami B, Bougacha L, Kolsi N, Mnif H, Chakroun A, Charfeddine I, Boudawara T, Ghorbel A: Primary sinonasal meningioma. Eur Ann Otorhinolaryngol Head Neck Dis 129:47-50, 2012

12. Morris KM, Campbell D, Stell PM, MacKenzie I, Miles JB: Meningiomas presenting with paranasal sinus involvement. Br J Neurosurg 4:511-515, 1990 
13. Petrulionis $M$, Valeviciene $\mathrm{N}$, Paulauskiene I, Bruzaite J: Primary extracranial meningioma of the sinonasal tract. Acta Radiol 46:415-418, 2005

14. Rushing EJ, Bouffard JP, McCall S, Olsen C, Mena H, Sandberg GD, Thompson LD: Primary extracranial meningiomas: An analysis of 146 cases. Head Neck Pathol 3:116-130, 2009

15. Spencer WR, Das K, Nwagu C, Wenk E, Schaefer SD, Moscatello A, Couldwell WT: Approaches to the sellar and parasellar region: anatomic comparison of the microscope versus endoscope. Laryngoscope 109:791-794, 1999
16. Thompson LD, Gyure KA: Extracranial sinonasal tract meningiomas: A clinicopathologic study of 30 cases with a review of the literature. Am J Surg Pathol 24:640-650, 2000

17. Wolff M, Rankow RM: Meningioma of the parotid gland: An insight into the pathogenesis of extracranial meningiomas. Hum Pathol 2:453-459, 1971 